\title{
TCF7L1 Gene
}

National Cancer Institute

\section{Source}

National Cancer Institute. TCF7L1 Gene. NCI Thesaurus. Code C150339.

This gene plays a role in catenin beta-1-dependent transcriptional regulation. 